THE CUTTER INCIDENT 



\section{THE CUTTER INCIDENT}

How America's First Polio Vaccine

Led to the Growing Vaccine Crisis

Paul A. Offit, M.D.

Yale University Press New Haven and London 
Copyright $\odot 2005$ by Paul A. Offit, M.D.

All rights reserved.

This book may not be reproduced, in whole or in part, including illustrations, in any form (beyond that copying permitted by Sections 107 and 108 of the U.S. Copyright Law and except by reviewers for the public press), without written permission from the publishers.

Set in Stemple Garamond type by Keystone Typesetting, Inc.

Printed in the United States of America by R. R. Donnelley \& Sons.

Library of Congress Cataloging-in-Publication Data

Offit, Paul A.

The Cutter incident : how America's first polio vaccine led to the growing vaccine crisis / Paul A. Offit.

p. cm.

Includes bibliographical references and index.

ISBN 0-300-10864-8 (cloth : alk. paper)

I. Poliomyelitis vaccine-History. 2. Poliomyelitis-Vaccination-United States-History.

3. Cutter Laboratories. 4. Vaccines-United States. I. Title.

QRI 89.5.P6O44 2005

6I $4 \cdot 5^{\prime} 49^{\prime} 0973-\mathrm{dc} 22$

2005040105

A catalogue record for this book is available from the British Library.

The paper in this book meets the guidelines for permanence and durability of the Committee on Production Guidelines for Book Longevity of the Council on Library Resources.

I0 $\quad 9 \begin{array}{lllllllll} & 8 & 7 & 6 & 5 & 4 & 3 & 2 & \text { I }\end{array}$ 
For Bonnie

and for our children,

Will and Emily 

The mass and majesty of this world, all

That carries weight and always weighs the same

Lay in the hands of others; they were small

And could not bope for belp, and no belp came

W. H. Auden 
